http://jmscr.igmpublication.org/home/

ISSN (e)-2347-176x ISSN (p) 2455-0450

crossref DOI: https://dx.doi.org/10.18535/jmscr/v7i8.161

Journal Of Medical Science And Clinical Research

\title{
To Evaluate the Effectiveness of Pulsed Ultrasound over Icing on DOMS in normal individuals
}

Author

\section{Sriram Nelakurthy}

\section{Introduction}

Delayed onset muscle soreness (DOMS) refers to skeletal muscles pain that follows prolonged repetitive eccentric exercises. The intensity of soreness starts increasing in first 24 hours and peaks at about 24 to 72 hours and subsides within 5 to 7 days following post-eccentric exercise. DOMS is a common ailment experienced many a times by most of the Individuals following unaccustomed activity of exercise. (Mac Intyre et al (1995)

It is proved that eccentric muscle contraction produces greater muscle soreness than concentric and isometric, and usually peaks at 448 to 72 hours post activity (Gulik and Kimura (1996). According to Cleak and Eston (1992) pain is not only the factor associated with DOMS but also there are associated laws of strength, loss of range of motion and swelling of the exercised muscle. In general, the sore muscles are described as stiff, tender, aching and decreased in muscle function.

Following repetitive eccentric muscle exercises, within 8 hours of initial injury chemo-attractants are released by the damaged muscle tissue. It attracts the neutrophils, which adhere to the endothelium of nearby blood vessels by a process called as margination. After adhesion, the neutrophils infiltrate into the muscle tissues and phagocytocise the damaged cells. If neutrophils function is not properly controlled, then the healthy muscle tissues maybe destroyed which can cause muscle damage. (Clarkson PM, 1999; Faulkner JA et. al, 1989 and Edwards SW, 1994). Mechanical disruption and inflammatory response of muscle fibers activate type III and type IV pain receptors leading to the sensation of pain in DOMS (O'Conner PJ (1999). The degree of soreness mainly depends on the extent of tissue damage and also on types of exercises. (new ham, 1983; Clarkson et al, 1992; Ebbeling et al, 1989)

The maximal eccentric contraction of different muscle shows soreness rating scale of a different value. The differences in soreness values are consistent with differences in their prolonged force loss and increased in the CK activity in the blood. Soreness results in swelling and increased swelling in the muscle. It is also found that there is an increase in muscle fiber size and intramuscular pressure in soreness.

DOMS is related to muscles structural damage, which is followed by ionic imbalance, inflammation and pain (Armstrong, R.B, 1984; Clarkson PM 1999). Muscle damage includes disrupted sarcolemma, T-tubules, microfibrils, cytoskeletal protein and sarcoplasmic reticulum. (Armstrong RB, 1984 and Clarkson PM et al 1998). Damage to sarcoplasmic reticulum is of great importance as it causes an ionic imbalance 
that activates "Calpain" an enzyme which further degrades muscle proteins (Clarkson and Sayers 1999).

Many theories have been tried to explain the etiology and process of DOMS. They are

- Lactic acid theory(Asmussen 1956)

- Tone tissue theory (Hough 1902)

- Tonic muscle spasms (Tebries 1961)

- Connective tissue damage (Asmussen 1956), Armstrong et. Al, 1979, Garrett WE et.al, 1984, Friden, et.al, 1983 )

- Tissue fluid theory (Stuber 1989 )

- Popping sarcomere hypothesis (Morgan 1990)

- Calcium hemostasis (Armstrong 1991, Clarkson and Sayers 1999)

- Inflammation theory (Clarkson et.al, 1992)

Lactic acid theory: This theory states that the anaerobic activity triggers lactic acid accumulation that might be the cause of DOMS. But later this theory was refuted by Schwane et.al and Waltrous et.al, as they have identified the relationship of lactic acid theory of DOMS was not matching.

Tone tissue theory: It has been stated that on genetical analysis, the markers of muscle injury differs from normal muscle size, which were seen in myoglobin. It has been described that the disruption of cellular components such as the Zline of disc Friden represents the weakest link in the mechanical chain. The myofibrillar damage was more dependent on peak tension rather than total average forces. Most of the ultrastructural (subcellular) damage was found in type II b fibers, as these fibers are having the weakest Z-bands in their mechanical chain.

Newham et.al, (1983) demonstrated the greatest level of DOMS occur in musculotendinous junction due to the rupture of myofibrillar tissue secondary to the releases of hydrolase's enzyme. Armstrong (1983) stated that inflammatory response in the muscle leads to degeneration of muscle fibers and microphage infiltration. Torn tissue theory also includes damage to sarcoplasmic reticulum and T-tubules. On microplasmic level of observation by Garrott and Duncan (1988) described that the weakest link of muscle is the musculotendinous junction.

Torn connective tissue theory: It states that, there is a selective damage to epimysium, perimysium, endomysium, fascia and tendons following DOMS. Following eccentric exercise there is always a selective recruitment of fast twitch muscle fibers. The disruption of sarcoplasmic reticulum in fast twitch muscle fibers alters the relaxation capacity of contracting muscle, which in turn causes a shear force between the muscle fiber units at the level of endomysium. Tulsan (1968) reported that the low hexose monophosphate shunt (HMS) activity in muscle is an indication that there is selective damage to the connective tissue as opposed to muscle. Following eccentric loading pain is associated with DOMS and can well be explained by the location of group IV sensory fiber in endomysium and fascia.

Connective tissue damage theory: The enzyme efflux from eccentric muscle activity involves several key substances such as hydroxy proline (Abraham, 1977), calcium ions, (Stauber WT 1989), creatinine phosphokinase (Byrnes, 1985), myoglobin(Asmussen 1956). The skeletal muscle enzyme effluxes of these substances are proportional to the intensity and duration of the eccentric exercise performed. Enzyme efflux mainly shows that the mechanism of altering the membrane permeability, fiber degeneration and necrosis following tissue damage in DOMS.

Tissue fluid theory: The enzyme efflux during DOMS was established as a diffusion gradient for fluid across the cellular membrane into extra cellular spaces that precipitates continues swelling or edema. According to Stauber (1989), the pain and swelling of DOMS resembles a mini compartment syndrome in the extracellular space and it is the most primary event in development of DOMS. Tissue fluid pressure was elevated in the muscle following exercise eccentrically but not concentrically. This type of intramuscular and extracellular swelling was also described by 
Howell et.al, (1985). The analogy of comparing the muscle to a water balloon would produce tension effects throughout the stroking thus resulting in pain, swelling and stiffness. Hasson et.al stated that the presence of tissue edema as an element of DOMS.

Popping sarcomere hypothesis: normally when the muscle is lengthened slowly, proportionately there is a lengthening of the sarcomere uniformly with increasing tension. Morgan (1990) theorized that there is a non uniform stretching takes place in sarcomeres following eccentric exercises and the sarcomeres reach to a point at which they are stretched too far causing damage. Morgan proposed that when a muscle is lengthened the weak sarcomeres are stretched to a length where they are only supported by passive elements and so easily get popped out. The transient force loss after the eccentric exercise could be due to damage within tendon attachments or the series of elastic elements of the muscle.

Calcium homeostasis: Damage to the muscle fibers after eccentric activity leads to damage of the sarcoplasmic reticulum which in turn will result in an increase in the level of intracellular calcium ions (Clarkson and Sayers 1999). The elevation of intracellular calcium ion levels may alter the ionic homeostasis and can cause cellular swelling. The raised level of calcium ions can be a factor for a muscle to be in a contracted state, hence cause the proteolytic enzyme accumulation thus extending the tissue damage (Armstrong 1991).

Inflammation: Muscle fiber damage following post eccentric muscle activity may cause an inflammatory response (Clarkson and Sayers 1999,Cleak and Eston 1992). In the process of inflammation neutrophils will be the first to infiltrate in to the area followed by leucocytes and macrophages. This shows the infiltration of inflammatory mediators causing increased osmotic pressure and in swelling the muscle which may be seen 24 hours after post exercise (Clarkson et.al, 1992).

Exercise induced muscle damage (EIMD) has been demonstrated that lengthening of muscle beyond $140 \%$ of its optimum length during eccentric contraction places an unaccustomed mechanical strain on the muscle. The stretching of the muscle by high force eccentric exercise causes a linear deformation of certain sarcomeres. It is found that following linear deformation there is disproportionate loss of strength in a shorter muscle, which lengthens in the days after eccentric exercise. Eccentric contraction clearly causes more muscle damage than either concentric or static contraction. Greater damage with eccentric contraction may not be related to metabolic fatigue but due to mechanical insult (Enoka RM 2001).

Following an EMG study it was found that activation patterns during maximal eccentric muscle actions could produce greater force output than both maximal concentric or static muscle actions. There is an increase in the motor unit synchronization and variability in the modulation of activity of motor unit following eccentric contraction.(Semmer 2000) when compared to concentric and static contractions (Jones 1997).

Ice exerts therapeutic affect on inflammation and edema through vasoconstriction and its beneficial if applied within 24 to 48 hours after injury. Arteriolar vasoconstriction is mediated through a sympathetic nervous pathway, which reduces bleeding in acute tension. The efficacy of cold in treating an acute injury is related to reduction of blood flow and metabolic demands within the tissue (Beirman W, Fried Lander M 1940). This helps to prevent secondary hypoxic injury, which is brought on by the initial inflammatory response. Overall ice helps in curtailing excessive edema formation and keeps the surrounding tissue viable. Following application of ice, the most important is the temperature gradient which cools the sub cutaneous adipose tissue and underlying muscles (Bierman W and Friedianer 1940). Cryotherapy has been shown to minimize the inflammatory response and so as the of functional recovery. Superficial cold applied to an exposed area causes uncomfortable sensation followed by burning, aching and finally the numbness (Prentice we, Bell GW 1990). The transition takes place in 5-10 
minutes duration where sensation results from the stimulation of large cutaneous nerve fibers. They relay impulses faster than the much smaller pain fibers (Lehman Jf, Delateur 1990). Cold application relieves pain of DOMS and rate of perceived soreness by two ways that are

1) Closure of the pain gate cycle by the activation of large diameter fibers and

2) Preventing the pain-spasm-pain cycle.

Ultrasound can have effect on target tissue only if the energy delivered reaches to the tissue and is absorbed. The depth of penetration is not intensity dependent but frequency dependent. In order to determine the appropriate frequency the depth target tissue must be ascertained. The $1 \mathrm{MHz}$ frequency ultrasound can heat tissues up to $3-5 \mathrm{~cm}$ deep while the $3 \mathrm{MHz}$ ultrasound penetrates only up to $2-3 \mathrm{~cm}$. The higher frequency the higher rate of absorption and attenuation. The most of ultrasonic energy with $3 \mathrm{MHz}$ frequency get absorbed in the superficial tissue whereas $1 \mathrm{MHz}$ frequency will have less energy absorbed superficially allowing for deeper absorption. In general with the higher intensity and frequency, the faster rate of heating with a $3 \mathrm{MHz}$ frequency can be 3-4 times faster than $1 \mathrm{MHz}$ frequency (Draper DO et.al,1995).

It has been found that the ultrasound has a positive effect on DOMS(Hasson et.al, 1990). The inflammatory phase begins when injury or disease causes a disruption in normal physiological function, which is characterized by swelling, heat, redness, pain and loss of function. During this phase ultrasound is used primarily for its nonthermal properties to facilitate the process of inflammation and therefore enhances healing. This is attributed to the accousting streaming of ultrasonic waves in the tissue that has been shown to increase the intracellular calcium, macrophages responsiveness, cell permeability, mast cell degranulation and histamine release. This effect has been attributed to pulsed ultrasound with a duty cycle of $20 \%$ at intensity of 0.5 watts $/ \mathrm{cm} 2$ or continuous mode at a very low intensity of 0.1 watts $/ \mathrm{cm} 2$.
Both thermal and non-thermal properties of ultrasound have shown to decrease the mechanism of pain. Pain reduction is unclear but it is thought that ultrasound may control pain by altering its transmission or perception due to the stimulation of cutaneous thermal receptors, by altering its nerve conduction velocity and increasing tissue temperature or modulation of inflammatory process (Fredorczyk J.1997).

\section{Aims and Objectives of the study}

1. To find out the effect of Pulsed ultrasound on DOMS in normal individuals.

2. To find out the effect of icing on DOMS in normal individuals.

3. To compare the effects of Pulsed ultrasound over icing on DOMS in normal individuals.

\section{Hypothesis}

1. Pulsed ultrasound may have an effect on reduction of symptoms of exercise induced DOMS in normal individuals.

2. Icing may have an effect on reduction of symptoms of exercise induced DOMS in normal individuals.

3. Pulsed ultrasound may be more effective in reducing the symptoms of exercise induced DOMS when compared to icing.

\section{Methodology}

\section{Sample selection}

Sampling: Stratified random sampling

Sampling selection: A total number of 107 subjects were screened out of which 50 subjects were selected for the study. Test sample consisted of 50 male volunteers in between the age group of 18 to 25 years (mean age $=21.5$ years). The subjects were selected from Srinivas Group of Colleges, Mangalore. The subjects were randomly divided into 2 groups of 25 each. The purpose of the study was explained to all the subjects and informed consent (Annexure-10.3) was obtained and demographic data were collected (Annexure10.1) from each subject. 
As the biceps brachii muscle is larger in diameter, the part to be treated was divided into two equal parts i.e., upper part and lower part for the treatment. Group A subjects of DOMS were treated with pulsed ultrasound for 5 mins to each part, a total of $10 \mathrm{~min}$ with $1 \mathrm{MHz}$ frequency, 1:4 pulsed ratio with an intensity of 0.8 watts $/ \mathrm{cm} 2$. Group B subjects with DOMS were treated with ice cube massage for 5 mins for each part of biceps with the circular technique for total time duration of 10 minutes.

Study design: Experimental study

Criteria for selection: Subjects for the study were selected based on the following criteria

\section{Inclusion criteria:}

1. Normal healthy male subjects in the age group of 18 to 25 years.

2. Subjects who have not undergone any upper limb exercise protocol since a month.

\section{Exclusion criteria:}

1. Subjects with current arm pathology and pain.

2. Subjects with any history of neuromusculoskeletal disorders, inflammatory disorders, recent upper limb fractures, cervical pathology.

\section{Materials used:}

1. Dumbbell (5 kg size)

2. Felt tipped pen

3. Towel (to use at measurement of range of motion)

4. A full circle transparent goniometer with long arms.(measurement is marked at every 1 degree in a total of 360 degrees, arm length of $30 \mathrm{~cm}$ )

5. Cotton (absorbable)

6. Aqua sonic ultrasound gel

7. Ultrasound machine (Phyaction 190i, CE 0344, Gymna uniphy NV, Belgium). The equipment used is of $1 \mathrm{MHz}$, intensity used for treatment of delayed onset muscle soreness is 0.8 watts $/ \mathrm{cm} 2$ for a time duration of 10 minutes with pulsed mode ratio of 1:4 over the biceps muscle area.
8. Cryotherapy unit (Karnataka medicals biomedical equipment)

9. Ice cube cups

10. Couch

\section{Procedure}

The normal range of motion was assessed actively with a universal double-armed transparent goniometer by placing the subjects in spine lying position. The VAS was considered as " 0 " for the entire subjects prior to experiment.

\section{Testing Protocol for ROM:}

Subjects were positioned in supine with shoulder in 0 degrees of flexion, extension and abduction so that rm is close to the side of the body. A pad was placed under the distal end of humerus so as to allow full elbow extension by positioning the forearm in full supination with palm of the hand facing the ceiling. The humerus was stabilized to prevent shoulder flexion and the pad was placed under the distal end of the humerus so as to avoid the extension of the shoulder. Initially normal end feel was tested. To measure ROM the fulcrum of the goniometer was placed over the lateral epicondyle of the humerus. The lateral midline of the humerusextended up to the centre of the acromion process and the lateral mid line of the radius touching radial styloid process were used as reference. (Cynthia C Norkins \& D. Joyce white $3^{\text {rd }}$ edition 2004).

\section{Testing Protocol for Visual Analog Pain Rating Scale (VAS):}

The subjects were explained about the VAS scale. A linear scale of $10 \mathrm{~cm}$ length with markings consisting from 0-10 was used. The left end of the scale was 0 and considered as no pain and the right end was 10 and considered as severe pain. The subject was asked to circle the number which best represents the intensity of his pain on that day.

DOMS was induced in all the subjects with a $5 \mathrm{~kg}$ dumbbell. The subjects were made to stand near the wall with their backs supported. The exercises were performed in such a manner that elbow 
flexion was completely passive i.e., assisted by therapist and elbow extension was completely active with concentric contraction of the biceps brachii. All the subjects were asked to perform these exercises until exhaustion which was noted by decrease in intensity of movement and inability to accomplish the movement fully. They were verbally encouraged to perform the activity until exhaustion i.e., taken as the point of onset for muscle soreness.

Post exercise, the elbow range of motion (ROM) and visual analogue pain (VAS) score were assessed and recorded. The subjects were instructed not to perform any form of exercise, stretching, massage, hot water fomentation, icing or use of anyof local or oral analgesics to get rid of pain. Following this procedure the subjects were called after $24,48 \& 72$ hours for further intervention. Each time the pre-treatment and post-treatment assessment of ROM and VAS scores were taken and documented.

Group A: subjects received treatment with ultrasound $[1 \mathrm{MHz}$ frequency, pulsed mode (1:4) and intensity 0.8 watts $/ \mathrm{cm} 2$ ]. A total duration of 10 minutes of treatment was administered. For each part (i.e., upper and lower parts of biceps) 5 mins treatment was given on the areas of pain as per their location on the biceps. The ROM and VAS score recordings were assessed and documented. The same procedure was repeated at 48 and 72 hours.

Group B: subjects were treated with ice massage for a period of 5 mins in each part as per the location of pain. A total of 10 mins of ice cube massage was administered. The ROM, VOS scores were assessed and documented. The same procedure was repeated for $48 \& 72$ hours.

\section{Results}

Table Mean, standard deviation and standard error of effect of ultrasound on range of motion following DOMS

\begin{tabular}{|l|c|c|c|}
\hline Days & Mean & Standard deviation & Standard error \\
\hline $\begin{array}{l}\text { Day0 } \\
\text { Pre-exercise }\end{array}$ & 144.5200 & 2.844878 & 0.568976 \\
\hline $\begin{array}{l}\text { Day 0 } \\
\text { Post-exercise }\end{array}$ & 136.1100 & 4.734624 & 0.946925 \\
\hline $\begin{array}{l}\text { Day1(24hours) } \\
\text { Pre-treatment }\end{array}$ & 133.1200 & 4.512206 & 0.902441 \\
\hline $\begin{array}{l}\text { Day1(24hours) } \\
\text { Post-treatment }\end{array}$ & 137.6800 & 2.688246 & 0.537649 \\
\hline $\begin{array}{l}\text { Day2(48hours) } \\
\text { Pre-treatment }\end{array}$ & 132.4400 & 6.850061 & 1.370012 \\
\hline $\begin{array}{l}\text { Day2(48hours) } \\
\text { Post-treatment }\end{array}$ & 135.9200 & 6.224414 & 1.244883 \\
\hline $\begin{array}{l}\text { Day3(72hours) } \\
\text { Pre-treatment }\end{array}$ & 135.3600 & 5.529316 & 1.105863 \\
\hline $\begin{array}{l}\text { Day3(72hours) } \\
\text { Post-treatment }\end{array}$ & 142.9600 & 2.908608 & 0.581722 \\
\hline
\end{tabular}

Table Mean, standard deviation \& standard error of icing on range of motion following DOMS

\begin{tabular}{|l|c|c|c|}
\hline Days & Mean & Standard deviation & Standard error \\
\hline $\begin{array}{l}\text { Day 0 } \\
\text { Pre-exercise }\end{array}$ & 145.6400 & 2.91376 & 0.582752 \\
\hline $\begin{array}{l}\text { Day0 } \\
\text { Post-exercise }\end{array}$ & 136.8400 & 5.962941 & 1.192588 \\
\hline $\begin{array}{l}\text { Day1(24hours) } \\
\text { Pre-treatment }\end{array}$ & 135.2800 & 6.692782 & 1.338556 \\
\hline $\begin{array}{l}\text { Day1(24hours) } \\
\text { Post-treatment }\end{array}$ & 136.6800 & 6.223075 & 1.244615 \\
\hline $\begin{array}{l}\text { Day2(48hours) } \\
\text { Pre-treatment }\end{array}$ & 133.1600 & 8.335066 & 1.667013 \\
\hline
\end{tabular}




\begin{tabular}{|l|c|c|c|}
\hline $\begin{array}{l}\text { Day2(48hours) } \\
\text { Post-treatment }\end{array}$ & 136.1600 & 9.826325 & 1.965265 \\
\hline $\begin{array}{l}\text { Day3(72hours) } \\
\text { Pre-treatment }\end{array}$ & 136.5600 & 5.694149 & 1.13883 \\
\hline $\begin{array}{l}\text { Day3(72hours) } \\
\text { Post-treatment }\end{array}$ & 140.4400 & 4.224137 & 0.844827 \\
\hline
\end{tabular}

Table Mean, standard deviation \& standard error of effect of ultrasound on pain scale following DOMS

\begin{tabular}{|l|c|c|c|}
\hline Days & Mean & Standard deviation & Standard error \\
\hline $\begin{array}{l}\text { Day0 } \\
\text { Post Ex }\end{array}$ & 4.2 & 0.707107 & 0.141421 \\
\hline $\begin{array}{l}\text { Day1(24hours) } \\
\text { Pre-exercise }\end{array}$ & 4.84 & 0.687992 & 0.137598 \\
\hline $\begin{array}{l}\text { Day1(24hours) } \\
\text { Post-treatment }\end{array}$ & 3.56 & 0.820569 & 0.164114 \\
\hline $\begin{array}{l}\text { Day2(48hours) } \\
\text { Pre-treatment }\end{array}$ & 4.10 & 0.768115 & 0.153623 \\
\hline $\begin{array}{l}\text { Day2(48hours) } \\
\text { Post-treatment }\end{array}$ & 3.24 & 1.011599 & 0.20232 \\
\hline Day3(72hours) Pre-treatment & 3.6 & 0.866025 & 0.173205 \\
\hline Day3(72hours) post-treatment & 1.6 & 0.57735 & 0.11547 \\
\hline
\end{tabular}

Table Comparison of ROM between days \& within days following application of ultrasound in DOMS

\begin{tabular}{|l|c|c|c|c|c|}
\hline Source & Df & SS & MS & F-ratio & F-table value \\
\hline Between days & 3 & 2211.735 & 737.245 & & \multirow{2}{*}{2.7134} \\
\hline Within days & 95 & 1757.622 & 18.50128 & 39.84831 & \\
\hline Total & 98 & 3969.357 & & & \\
\hline
\end{tabular}

Table Comparison of ROM between days and within days following application of ice in DOMS

\begin{tabular}{|l|c|c|c|c|c|}
\hline Source & Df & SS & MS & F-ratio value & F-table value \\
\cline { 1 - 4 } Between days & 3 & 2561.006 & 853.6687 & \multirow{2}{*}{32.95922} & \multirow{2}{*}{2.7134} \\
\cline { 1 - 4 } Within days & 95 & 2460.572 & 25.90076 & & \\
\hline Total & 98 & 5021.578 & & & \\
\hline
\end{tabular}

*significant $(\mathrm{p}<0.05)$

Table Comparison of effectiveness of ultrasound and icing on pain following DOMS

\begin{tabular}{|c|c|c|c|c|}
\hline Days & Treatment & Mann-whitney & Mean rank & "p-value" (2-tailed)** \\
\hline \multirow[t]{2}{*}{$\operatorname{PostEx}(0)$} & Ultrasound & \multirow[t]{2}{*}{250.000} & 28.00 & \multirow[t]{2}{*}{0.187} \\
\hline & Icing & & 23.00 & \\
\hline \multirow[t]{2}{*}{ Day1 pre-treatment } & Ultrasound & \multirow[t]{2}{*}{261.000} & 23.44 & \multirow[t]{2}{*}{0.261} \\
\hline & Icing & & 27.56 & \\
\hline \multirow[t]{2}{*}{ Day1 post treatment } & Ultrasound & \multirow[t]{2}{*}{260.000} & 23.40 & \multirow[t]{2}{*}{0.255} \\
\hline & Icing & & 27.60 & \\
\hline \multirow[t]{2}{*}{ Day2 pre-treatment } & Ultrasound & \multirow[t]{2}{*}{283.000} & 24.32 & \multirow[t]{2}{*}{0.536} \\
\hline & Icing & & 26.68 & \\
\hline \multirow[t]{2}{*}{ Day2 post treatment } & Ultrasound & \multirow[t]{2}{*}{311.000} & 25.56 & \multirow[t]{2}{*}{0.975} \\
\hline & Icing & & 25.44 & \\
\hline \multirow[t]{2}{*}{ Day3 pre-treatment } & Ultrasound & \multirow[t]{2}{*}{264.500} & 27.42 & \multirow[t]{2}{*}{0.315} \\
\hline & Icing & & 23.58 & \\
\hline \multirow[t]{2}{*}{ Day3 post treatment } & Ultrasound & \multirow[t]{2}{*}{207.000} & 21.28 & \multirow[t]{2}{*}{$0.020^{*}$} \\
\hline & Icing & & 29.72 & \\
\hline
\end{tabular}

*significant $\mathrm{p}=<0.05$ 
Table Comparison of the effectiveness of ultrasound on pain following DOMS

\begin{tabular}{|l|c|c|c|}
\hline Group & Mean difference & $\mathbf{Z}^{* *}$ Wilcoxson & p-value \\
\hline $\begin{array}{l}\text { Pre-treatment(day1) } \\
\text { Post Ex(day0) }\end{array}$ & 0.64 & 3.689 & $0.000^{* * *}$ \\
\hline $\begin{array}{l}\text { Post Ex (0) } \\
\text { Post treatment(day1) }\end{array}$ & 0.64 & 2.12 & $0.035^{* *}$ \\
\hline $\begin{array}{l}\text { Pre-treatment(day2) } \\
\text { Post Ex(0) }\end{array}$ & 0.1 & 2.01 & $0.021^{* *}$ \\
\hline $\begin{array}{l}\text { Post Ex(day0) } \\
\text { Post treatment(day2) }\end{array}$ & 0.96 & 2.515 & $0.012^{* *}$ \\
\hline $\begin{array}{l}\text { Pre-treatment(day3) } \\
\text { Post Ex(day0) }\end{array}$ & 0.6 & 1.883 & 0.000 \\
\hline $\begin{array}{l}\text { Post Ex(day0) } \\
\text { Post treatment(day3) }\end{array}$ & 2.6 & 4.358 & $0.000^{* * *}$ \\
\hline$* * *$ highly significant $\mathrm{p} \leq 0.005$ level & & \\
$* * *$ very highly significant $\mathrm{p} \leq 0.001$ level &
\end{tabular}

Table Comparison of the effectiveness of icing on pain following DOMS

\begin{tabular}{|l|c|c|c|}
\hline Group & $\begin{array}{c}\text { Mean } \\
\text { difference }\end{array}$ & $\begin{array}{c}\text { Z*** } \\
\text { (Wilcoxson) }\end{array}$ & “p-value" \\
\hline $\begin{array}{l}\text { Pre-treatment (day1) } \\
\text { PostEx (day0) }\end{array}$ & -1.1 & 4.716 & $0.000^{* * *}$ \\
\hline $\begin{array}{l}\text { Post Ex (0) } \\
\text { Post treatment (day1) }\end{array}$ & -1.16 & 0.632 & 0.527 \\
\hline $\begin{array}{l}\text { Pre-treatment (day2) } \\
\text { PostEx (0) }\end{array}$ & 0.008 & 2.558 & $0.011 * * *$ \\
\hline $\begin{array}{l}\text { Post Ex (day0) } \\
\text { Post-treatment (day2) }\end{array}$ & -0.68 & 2.612 & $0.009 * * *$ \\
\hline $\begin{array}{l}\text { Pre-treatment (day3) } \\
\text { Post Ex (day0) }\end{array}$ & 0.72 & 2.503 & $0.012 * * *$ \\
\hline $\begin{array}{l}\text { Post Ex (day0) } \\
\text { Post-treatment (day3) }\end{array}$ & 2.04 & 4.449 & $0.000^{* * *}$ \\
\hline \multicolumn{2}{|l|}{$* * *$ very highly significant $\mathrm{p} \leq 0.001$ level } & & \\
\hline
\end{tabular}

Graph 1 Comparison of the effectiveness of ultrasound and icing on ROM in DOMS

\section{Chart Title}

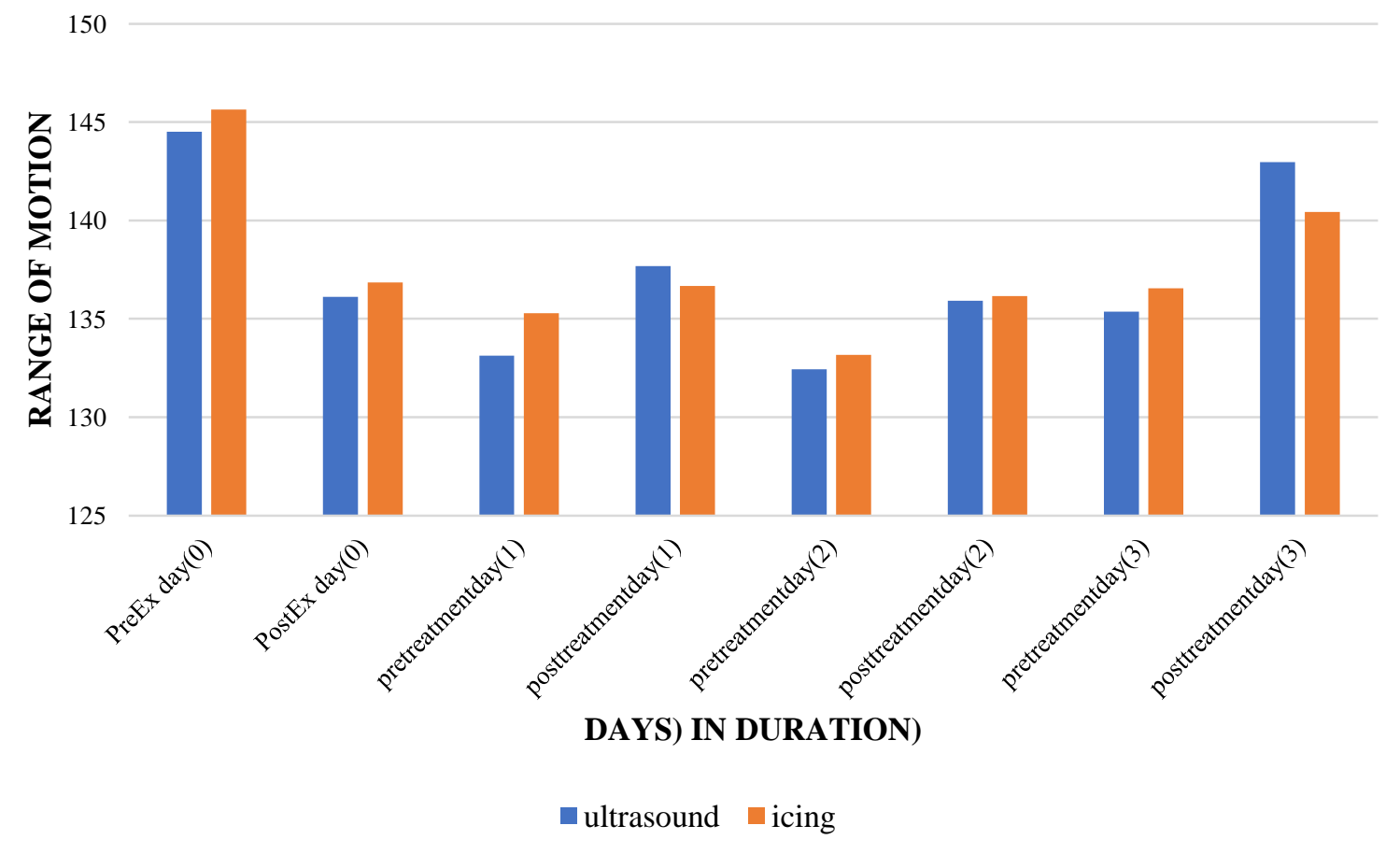


Graph 2 Comparison of the effectiveness of ultrasound and icing pain scale in DOMS

\section{Chart Title}

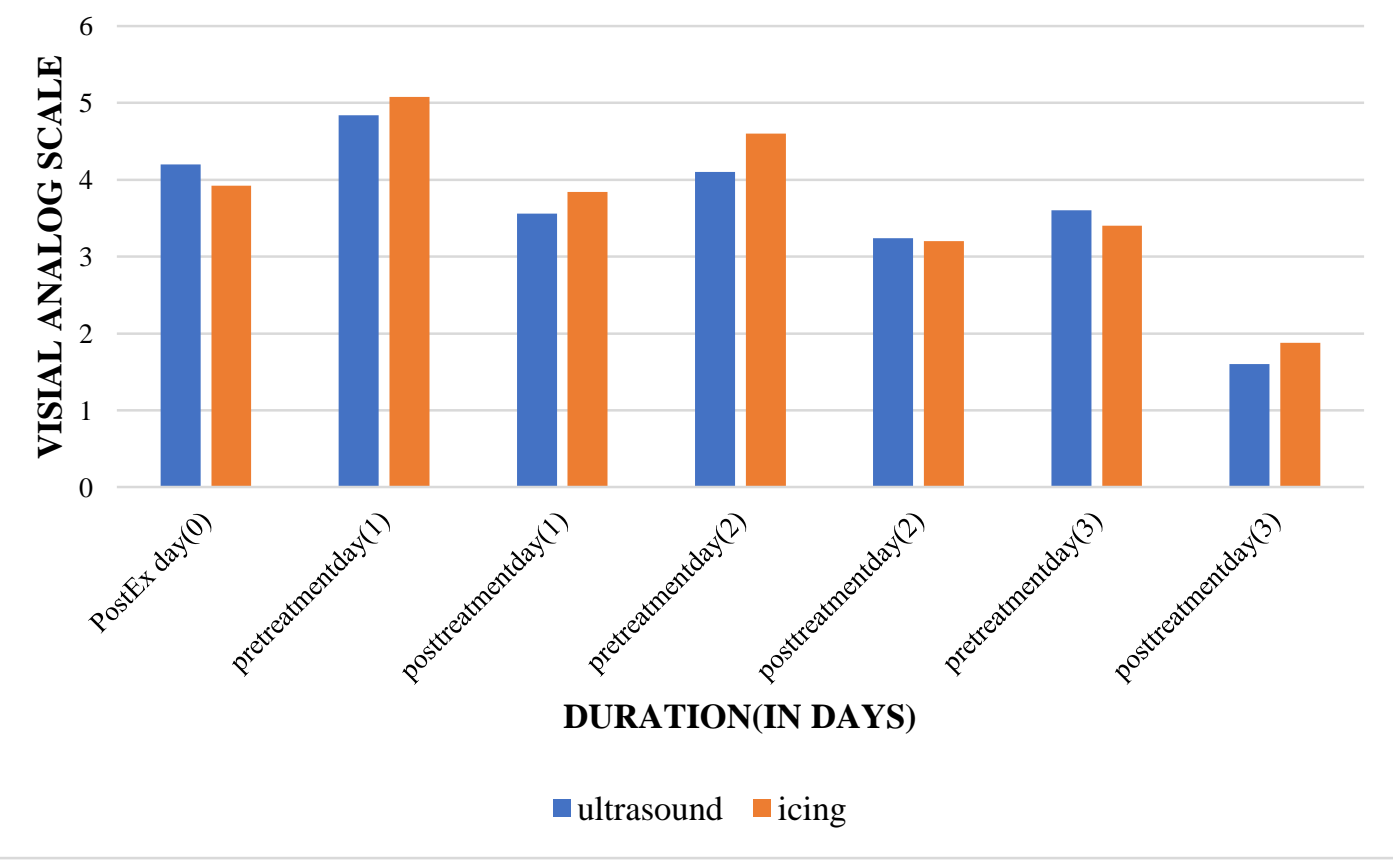

\section{Discussion}

Delayed Onset of Muscle Soreness (DOMS) is a condition signified by soreness at an early stage and pain with decrease in range of motion (ROM) both early and late stage which normally follows an unaccustomed activity or an eccentric muscular activity in an individual. Normally the acute soreness occurs in the muscles at the time of activity, whereas DOMS is seen after 24 hours. The symptoms of DOMS include pain, loss of strength, loss of ROM \& swelling. The symptoms of DOMS commonly appear in sports persons, which should be intervened effectively before the performance of the athlete in affected.

There are many treatment modalities available in physiotherapy but there is a lack of evidence regarding their effectiveness on DOMS. Though there are many conventional therapeutic exercises \& electro physical treatments available for treatment of DOMS, most of the researches have given a controversial statements on the treatment modalities. Ice and ultrasounds are the most commonly used modalities in soft tissue injuries. Many studies found out the effectives of ultrasound and icing on DOMS, but comparison of both the modalities have been least analysed.
The aim of the study was to find out the comparison of ultrasound over icing on DOMS. From analysis the result showed that there is a significant difference between the treatment days i.e., day (0) post-exercise to post treatment days on both ultrasound and icing which proves their effectiveness on DOMS.

The present study also aimed at finding out the effectiveness of ultrasound over ice on ROM following DOMS. Day wise comparison was made between the groups. It was found that only on post treatment day 3 the difference in their ROM was statically significant $(\mathrm{p}=0.017)$.

The result of this study supports the hypothesis and found that both ultrasound and icing have an effect on reducing the symptoms of DOMS. On further analysis it also supported the hypothesis that ultrasound is more effective in reducing the symptoms of DOMS when compared with icing treatment. It has been found that ultrasound and ice treatment were effective upto 48 hours. It shows following ultrasound that there is an increase in ROM and decrease in pain score at 72 hours post treatment period. The causes maybe : 1) less fluid filtration into the interstitium following to vasoconstriction, 2) less 
inflammation and less pain and 3) a decrease in metabolic rate resulting in hypoxic injury (Susan L michlovitz) Application of ultrasound increases the calcium levels, which alters the enzymatic activity of cells and their synthesis and secretion of proteins. The changes in the intracellular calcium levels following treatment by ultrasound (pulsed) 20\% (Mortimer AJ, Dyson M 1998) can affect the macrophage response and tissue repair in the inflammatory phase. (Dinno MA, Crum LA 1989). From this study it can be said that ultrasound can be used as a method of choice for the treatment of patients with delayed onset muscle soreness than icing.

\section{Limitations of the study}

1) There was no control group due to ethical reasons.

2) Only males were taken for the study.

3) Age group was limited to 18-25 years.

4) Sample size was limited to 50.

\section{Recommendations for future study are}

1) On naturally occurring delayed onset muscle soreness

2) On effectiveness of other physiotherapeutic modalities

3) Ultrasound and cryotherapy treatment on DOMS on female

\section{Conclusion}

Both ice massage and ultrasound are the effective modalities in the treatment of exercise induced delayed onset muscle soreness up to a period of 48hours. Further the ultrasound (pulsed) is effective up to 72 hours.

\section{Bibliography}

1. Maclntyre DL, Reid WD and McKenzie DC. Delayed muscle soreness. Sports medicine 1995; 20:24-40
2. Gulick DT and Kimura IF Delayed onset muscle soreness: what is it and how do we treat it ? Journal of sports rehabilitation 1996; 5:234-243

3. Cleak MJ and RG Eston: Delayed onset muscle soreness: Mechanisms and management. Journal of sports sciences. 1992: 10:325-341

4. Clarkson PM and SP Sayers etiology of exercise induced muscle damage. Canadian journal of applied physiology.1999; 24: 234-248

5. Faulkner JA, Jones DA, Round JM: Injury to skeletal muscles of mice by forced lengthening during contractions. Q J Exp Physiol 1989; 74:661-70

6. Edwards RH: Human muscle function and fatigue. Ciba found sympo 1981; 82:1-18

7. O'Connor PJ, Cook DB: Exercise and pain; The neurobiology, measurement and laboratory study of pain in relation to exercise in humans. Exerc Sport Sci Rev 1999; 27:119-66

8. Newham DJ, Mills KR, Quigley BM et.al : Pain and fatigue after concentric and eccentric muscle contractions. Clin Sci (cloch) 1983; 64:55-62

9. Clarkson PM, Nosaka $\mathrm{K}$ and Braun : Muscle function after exercise induced muscle damage and rapid adaptation. Medicine and science in sports and exercise 1992; 25:512-520

10. Ebbeling CB, Clarkson PM Exercise induced muscle damage and adaptation sports med 1989; 7:207-34. 